\title{
The Influence of Ice-Resistant Coatings Characteristics to the Energy Efficiency of Ice- Going Ships
}

\author{
V.A. Veselov ${ }^{1}, M . V$. Kitaev $^{1 *}$, P.O. Pastukhov ${ }^{2}$ and O.E. Surov ${ }^{1}$ \\ ${ }^{1}$ Department of Marine engineering and Transport, Polytechnic Institute, Far Eastern Federal \\ University, Vladivostok, Russia \\ ${ }^{2}$ Far Eastern State Technical Fisheries University, Engineering Disciplines Department, 52B \\ Lugovaya Str., Vladivostok 690087, Russia
}

\begin{abstract}
The main purpose of ice-resistant coatings designed for icebreakers and ice navigation ships is the ability to protect of the ship's hull in the most severe operating conditions. The special coatings certified by the Classification Societies for ice abrasion can provide this protection. These coatings allow to reduce the required thickness of the ship's hull and reduce the construction weight of the ships. On the other hand, these coatings must have a low friction coefficient, which reduce the frictional resistance of the hull on ice and fuel consumption, increase the service life of the ship and power plant, reduce $\mathrm{CO}_{2}$ emissions into the atmosphere and affect to the operational and economic efficiency of the ship. In this paper, we present the results of experimental tests of friction coefficient on ice for various types of ice-resistant coatings and analysis the influence of ice-resistant coatings characteristics to the energy efficiency of ice-going ships.
\end{abstract}

\section{Introduction}

Friction forces have an important role in technique. The positive influence of friction forces we see as a holding object on an inclined plane or damping the forces of inertia when the ship is rolling. Also friction has a negative impaction on processes, for example, friction during the rotation of bearings and shaft lines, during the movement of the ship in ice. The negative friction effect leads to inefficient usage of energy and other resources and increase losses of energy [1].

To reduce the friction part of ship resistance of conventional displacement vessels, their outer skin usually is thoroughly cleaned and painted with special paints that reduce the friction and prevent fouling of the hull when ship stay in a port. For ice navigation vessels or ice-going ships (icebreakers) the problem is more complex as special requirements usually are used. Such types of coatings should protect the hull in the harshest operation conditions, reduce ice resistance, friction effect and increase the strength of shell expansion. Totally, these coatings have a positive effect implementing to economic and functional efficiency of

\footnotetext{
*Corresponding author: kitaev.mv@dvfu.ru
} 
the vessel - reduced fuel consumption, increase service life of the shell expansion and the motoresource of the main engine, reduced $\mathrm{CO} 2$ emission and etc.

These special coatings are certified by the International Ship Classification Societies as ice resistance and anti-abrasion coatings. Depending on the manufacturer of such coatings, their properties and characteristics may be differ and have a different affect to operational and energy efficiency of aship in ice conditions.

At present work the research result of friction coefficient for different types of ice resistance coatings and manufacturers are presents and shows the influence of the coatings to the efficiency of the ice-going ships and icebreakers.

\section{Requirements to ice-resistant coatings}

The ice-resistant coatings (IRC) are capable to protect the shell expansion of the ship's hull from external conditions during the ice navigation. The general demands to these types of coatings are presented in Rules for the Classification and Construction of Marine Vessels, Part XIII [2] of the Russian Maritime Register of Shipping (RMRS).

Besides, this status means that this coating allows to reduce the hull plates and constructions thickness required by the RMRS Rules. This fact leads to total ship's weight and building cost reduction and besides the ship owner can increase the operation efficiency of the vessel [3].

The criteria for the assessment of experimental test results during certification and standard approval of the ice resistance coating, used until the 2021 by the Russian Maritime Register of Shipping (Rules for the Classification and Construction of Marine Vessels of Part XIII "Materials"), are shown in Table 1.

Table 1. Criteria for the evaluation of IRC [2]

\begin{tabular}{|c|c|c|c|c|}
\hline \multirow{3}{*}{ Characteristic } & \multicolumn{4}{|c|}{$\begin{array}{l}\text { Values } \\
\end{array}$} \\
\hline & \multicolumn{2}{|c|}{$\begin{array}{l}\text { Group } 1 \text { for icebreakers of } \\
\text { all ice classes }\end{array}$} & \multicolumn{2}{|c|}{$\begin{array}{l}\text { Group } 2 \text { for Arc4 and } \\
\text { above ice class ships }\end{array}$} \\
\hline & Class I & Class II & Class I & Class II \\
\hline $\begin{array}{l}\text { Durability as per ISO } 12944-6 \text { for a } \\
\text { corrosivity category Im2 in compliance } \\
\text { with ISO } 12944-2\end{array}$ & \multicolumn{2}{|c|}{ High } & \multicolumn{2}{|c|}{ High } \\
\hline $\begin{array}{l}\text { Adhesion by a cross-cut test method as } \\
\text { per ISO } 2409 \text { or X-cut test method as } \\
\text { perISO16276-2 after testing for } \\
\text { resistance to low temperature exposure } \\
\text { depending on the thickness and type of } \\
\text { ice resistant coating. }\end{array}$ & \multicolumn{2}{|c|}{$\leq 3$} & \multicolumn{2}{|c|}{$\leq 3$} \\
\hline Adhesion strength as per ISO 4624 & $\geq 16 \mathrm{MPa}$ & $\geq 16 \mathrm{MPa}$ & $\geq 16 \mathrm{MPa}$ & $\geq 16 \mathrm{MPa}$ \\
\hline $\begin{array}{l}\text { Abrasive wear after } 1000 \text { cycle tests on } \\
\text { the Taber's abrader (wheel CS-17) }\end{array}$ & $\leq 80 \mathrm{mg}$ & $\leq 120 \mathrm{mg}$ & $\leq 120 \mathrm{mg}$ & $\leq 160 \mathrm{mg}$ \\
\hline Impact resistance as per ISO 6272 & \multicolumn{2}{|c|}{$\leq 5 \mathrm{~J}$} & \multicolumn{2}{|c|}{$\leq 5 \mathrm{~J}$} \\
\hline $\begin{array}{l}\text { Cathode disbandment as per ISO } 15711 \\
\text { for coatings compatible with cathode } \\
\text { protection }\end{array}$ & \multicolumn{2}{|c|}{$\begin{array}{l}\text { less than } 5 \mathrm{~mm} \text { after three } \\
\text { month testing, less than } 8 \\
\text { mm after six month testing }\end{array}$} & \multicolumn{2}{|c|}{$\begin{array}{l}\text { less than } 5 \mathrm{~mm} \text { after three } \\
\text { month testing, less than } 10 \\
\text { mm after six month testing }\end{array}$} \\
\hline Coefficient of sliding friction for ice & $\leq 0,05$ & $\leq 0,08$ & $\leq 0,05$ & $\leq 0,08$ \\
\hline
\end{tabular}




\section{The research of friction coefficients of IRC}

\subsection{Manufacturers of IRC}

The 15 IRC samples of various manufacturers under the laboratory conditions were tested $(2018$ - 2020) in Ice Laboratory of FEFU.

The IRC were covered by the manufacturers in according the data sheet. We tested the IRC such manufacturers as shown in Table 2.

Table 2. IRC Manufacturers

\begin{tabular}{|c|c|}
\hline Manufacturer & Number of IRC \\
\hline JSC «Russian coatings» & 1 \\
\hline «Akrus», Co. LTD & 2 \\
\hline «Emlak», Co. LTD & 1 \\
\hline «RPU 812», Co. LTD & 6 \\
\hline «PPG Industries», Inc. & 3 \\
\hline «Jotun», Co. Ltd. & 1 \\
\hline «Hempel Korea», Co. Ltd. & \\
\hline
\end{tabular}

The examples of tested IRC with samples are shown in Figure 1.

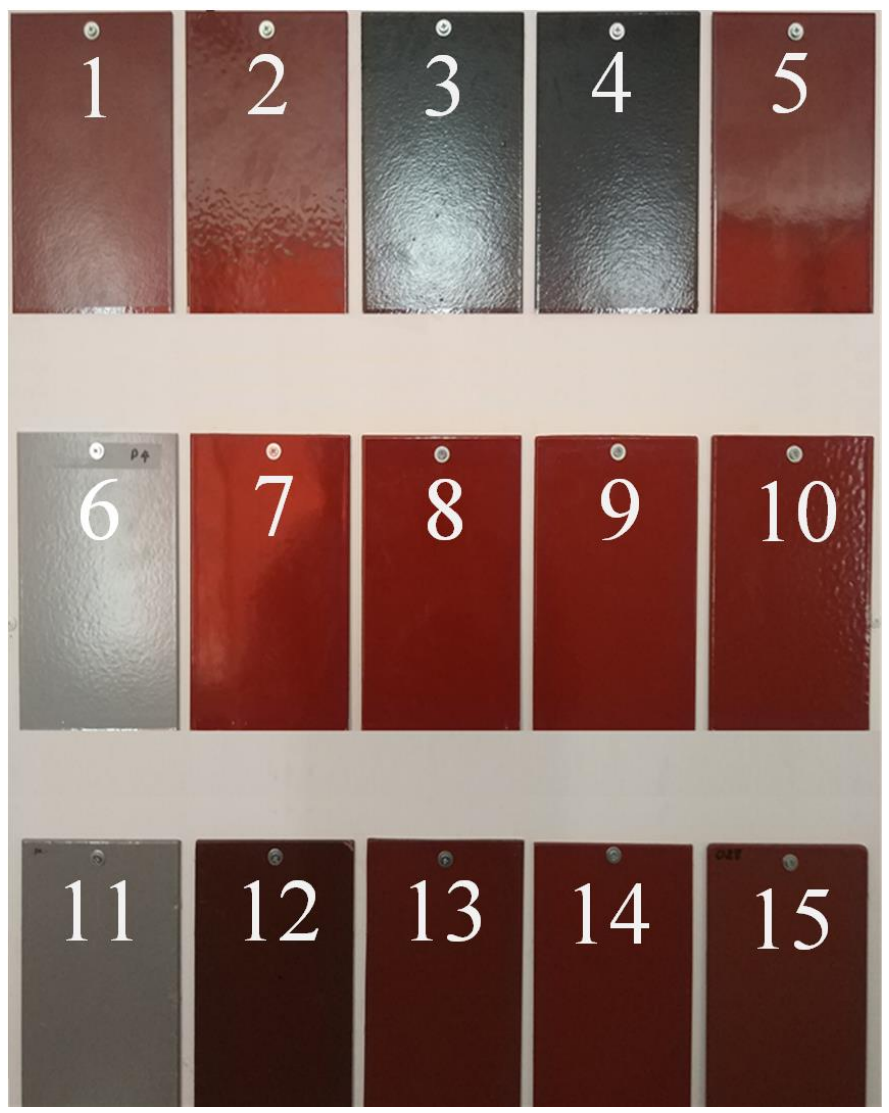

Fig. 1. Samples of Ice resistant coatings. 


\subsection{Tools and equipment}

The following tools and equipment for IRC tests were used:

- laboratory unit equipped with a compartment (reservoir) for placing fresh ice, including a mechanism for vertical.

- pressing force applied to the sample coated with IPC and the longitudinal travel mechanism pre-adjusted to a speed, a gauge for monitoring of friction force of specimen covered with IPC on ice.

- a personal computer with special software for recording the vertical loads and friction forces during the longitudinal shifting of the specimen with IPC relatively to ice.

- video recording device.

- climatic room.

\subsection{Method of testing and conditions}

A specimen with applied IRC is fixed in a laboratory set. The specimen is placed on fresh ice obtained from distilled water. Then operator applied a vertical - down force to the specimen. The longitudinal movement travel mechanism with pre-adjusted to a speed of shall be switched on.

Test procedure in accordance with the requirements of ch. 2.5.7 of the Rules for the Classification and Construction of Marine Vessels, Part XIII "Materials" of the Russian Maritime Register, are carried out under the following conditions [2]:

- temperature $-20^{\circ} \mathrm{C}$;

- relative humidity not more $85 \%$;

- atmosphere pressure 1 bar.

To perform tests, the bearing plane recess shall be filled with distilled water cooled to the ambient temperature $-(20 \pm 2)^{\circ} \mathrm{C}$ and held within the time necessary for ice formation. Panels for tests shall be rectangular dimensioned $(250 \times 130 \times 3( \pm 0,5)) \mathrm{mm}$. Before testing, the specimens shall be conditioned at the temperature of $(-20 \pm 2)^{\circ} \mathrm{C}$ for at least 15 minutes. Tests shall be carried out under standard conditions at the temperature of $(-20 \pm 2)^{\circ} \mathrm{C}$. A panel with applied coating shall be placed on the bearing plane $\mathrm{B}$ and fixed in the device. Then the travel mechanism pre-adjusted to the specified speed shall be switched on. Due to the frictional loads between the adjoining surfaces of the specimen and ice, they can remain fixed relative to each other until the force shifting the sample becomes equal to or exceeds the static friction force between the surfaces. That maximum initial force value shall be marked as a force, which is a component of the initial (static) coefficient of friction. The average force value shall be visually marked or marked by means of strain gauges, as read on the indicator scale with a uniform movement of the surfaces relative to each other for $1 \mathrm{~min}$. This force is equal to the kinetic sliding friction force, which is necessary to maintain the uniform, linear surfaces movement relative to each other. To assess sustainability of results three panels of each coating type shall be tested with the speed of 120,150 and $180 \mathrm{~mm} / \mathrm{min}$ varying three variants of vertical load (uniformly distributed along the specimen) taken within 2 - 5 mass range of the test panel [2].

\subsection{Results assessment}

The coefficient of initial (static) friction is calculated as follows:

$$
\mu_{S}=\frac{T_{S}}{N}
$$

where $T_{S}$ - initial motion scale reading, in $\mathrm{g} ; N$ - vertical loads including the specimen weight, in $\mathrm{g}$. 
The (kinetic) coefficient of sliding friction is calculated as follows:

$$
\mu_{K}=\frac{T_{K}}{N}
$$

where $T_{K^{-}}$average scale reading obtained during uniform sliding of surfaces, in $\mathrm{g}$.

The algorithm accuracy for assessment of test results is approved in accordance with ISO 5725. «Accuracy (correctness and precision) of measurement methods and results»[6].

Measurement gages precision - 0,50\%. After the tests operator performed a visual inspection of the specimens. The test results are drawn up in the form of a test report prepared in the prescribed form. The adjustment of test equipment is carried out in accordance with the technological instructions of the laboratory set.

The examples of experimental test results are shown on Figure 2, 3.

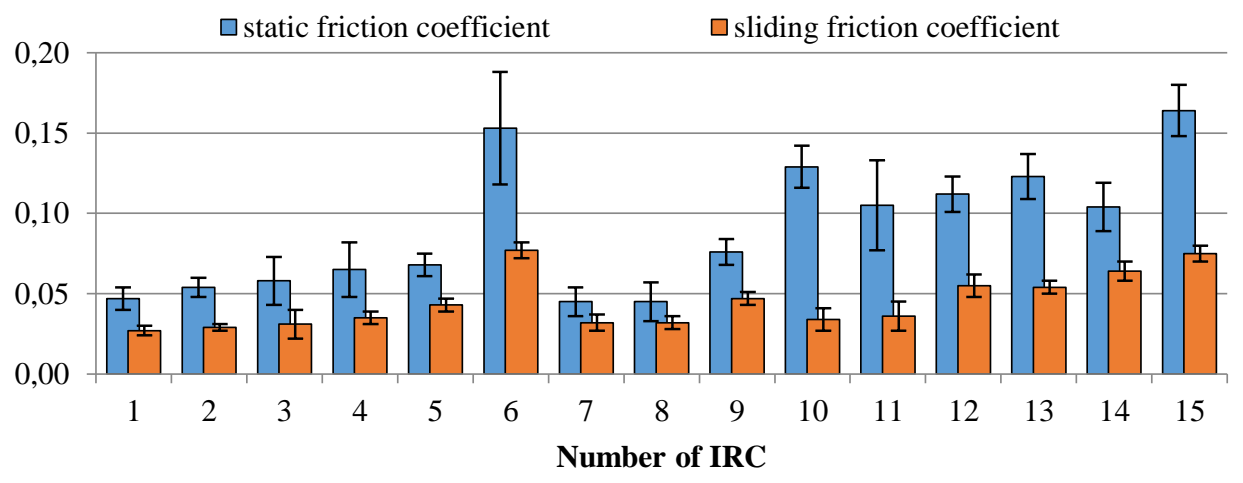

Fig. 2. The results of experimental tests.

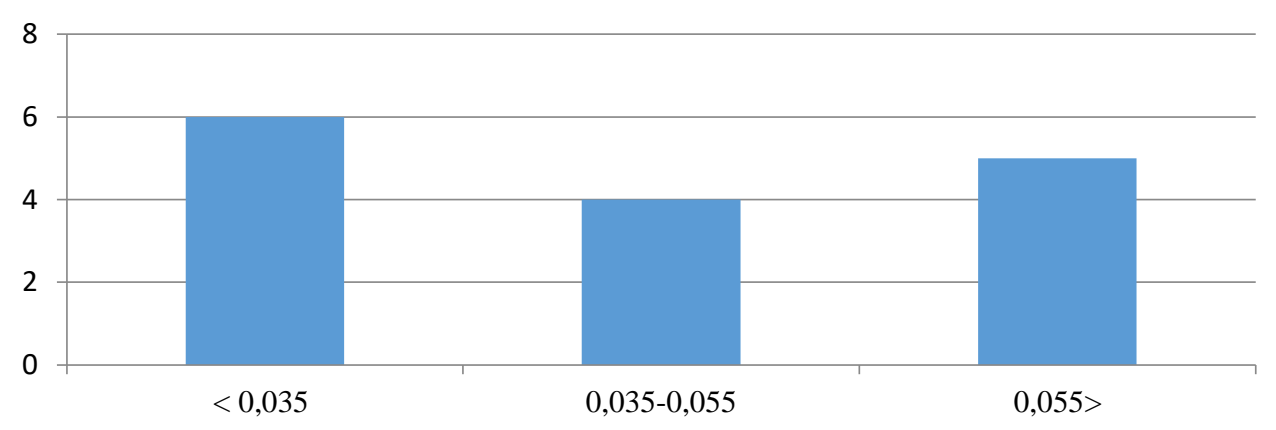

Fig. 3. Histogram of friction coefficients distribution of IRC.

From the analysis of experimental data we can conclude that the most of tested samples covered with IRC are correspond to the first class, first group, in according with the data of Table 1. These IRC can be used for icebreakers of all classes of ice-going ships.

\section{Effect of the coefficient of friction on ice resistance}

At low speeds, especially when the ship is moving in solid ice, the friction forces make a significant contribution to the total resistant balance. In according with [7], the friction component of total resistant in ice conditions is about $30 \%$. The ratios of the ice resistance components are shown in Table 3.

As an example, the comparison calculated and experimental data in the view of ratios of ice resistance components for icebreaker «Moskva» are shown in Table 3 [7]. 
Table 3. Comparison calculated and experimental data (in \%)

\begin{tabular}{|c|c|c|c|c|c|c|c|}
\hline \multirow{2}{*}{$\begin{array}{l}\text { Relative components } \\
\text { of ice resistance }\end{array}$} & \multicolumn{2}{|c|}{$\mathrm{R}_{1} / \mathrm{R}$} & \multicolumn{2}{|c|}{$\mathrm{R}_{2} / \mathrm{R}$} & \multicolumn{2}{|c|}{$\mathrm{R}_{3} / \mathrm{R}$} & \multirow{2}{*}{$\mathrm{R}_{\mathrm{F}} / \mathrm{R}$} \\
\hline & $\mathrm{R}_{\sigma} / \mathrm{R}$ & $\mathrm{R}_{\mathrm{f \sigma}} / \mathrm{R}$ & $\mathrm{R}_{\mathrm{S}} / \mathrm{R}$ & $\mathrm{R}_{\mathrm{fs}} / \mathrm{R}$ & $\mathrm{R}_{v} / \mathrm{R}$ & $\mathrm{R}_{\mathrm{fv}} / \mathrm{R}$ & \\
\hline \multirow{2}{*}{$\begin{array}{l}\text { Calculated values } \\
\text { according to the } \\
\text { updated formula }\end{array}$} & \multicolumn{2}{|c|}{49,1} & \multicolumn{2}{|c|}{39,2} & \multicolumn{2}{|c|}{11,7} & \multirow[b]{2}{*}{29,1} \\
\hline & 34,3 & 14,8 & 28,0 & 11,2 & 8,6 & 3,1 & \\
\hline \multirow{2}{*}{$\begin{array}{l}\text { Calculated values } \\
\text { according to the } \\
\text { approximate formula }\end{array}$} & \multicolumn{2}{|c|}{51,2} & \multicolumn{2}{|c|}{36,9} & \multicolumn{2}{|c|}{11,9} & \multirow{2}{*}{28,5} \\
\hline & 36,1 & 15,1 & 26,3 & 10,6 & 9,1 & 2,8 & \\
\hline Experimental values & \multicolumn{2}{|c|}{46,5} & \multicolumn{2}{|c|}{40,6} & \multicolumn{2}{|c|}{12,9} & 30,0 \\
\hline
\end{tabular}

where:

- $\mathrm{R}$ - total ice resistance;

- $\mathrm{R}_{1}$-ice breaking component;

- $\mathrm{R}_{2}$ - submersion and rotation component;

- $\mathrm{R}_{3}$ - pushing component;

- $\mathrm{R}_{\mathrm{F}}$-friction component.

In this case, the total ice resistance can be described as [7]:

where:

$$
\mathrm{R}=\mathrm{R}_{\sigma}+\mathrm{R}_{f \sigma}+\mathrm{R}_{\mathrm{S}}+\mathrm{R}_{\mathrm{fs}}+\mathrm{R}_{v}+\mathrm{R}_{\mathrm{fv}}+\mathrm{R}_{\mathrm{B}}
$$

$-\mathrm{R}_{\sigma}+\mathrm{R}_{f \sigma}=\mathrm{R}_{1}$;

$-\mathrm{R}_{\mathrm{S}}+\mathrm{R}_{\mathrm{fs}}=\mathrm{R}_{2}$

$-\mathrm{R}_{v}+\mathrm{R}_{\mathrm{fv}}=\mathrm{R}_{3}$

- $\mathrm{R}_{\sigma}$ - part of resistance caused by the destruction of ice;

- $\mathrm{R}_{f \sigma}$ - part of resistance caused by the friction when destruction the ice;

- $\mathrm{R}_{\mathrm{S}}$ - part of resistance caused by the submersion and rotation of floe ice;

- $\mathrm{R}_{\mathrm{fs}}$-part of resistance caused by the friction when submersion and rotation of floe ice;

- $\mathrm{R}_{v}$ - part of resistance caused by the pushing of ice;

- $R_{f v}$-part of resistance caused by the friction when pushing the ice;

- $R_{B}$ - water resistance, but since it is a thousandth of ice resistance, then it can be ignored. The total friction resistance component can be written as:

$$
\mathrm{R}_{\mathrm{F}}=\mathrm{R}_{f \sigma}+\mathrm{R}_{\mathrm{fs}}+\mathrm{R}_{\mathrm{fv}}
$$

The calculation of total resistance in Table 3 were performed with assumption $\mu_{K}=0.08$ [7]. But the experimental test results show that the maximum value of IRC friction coefficient is 0.077 , and the minimum value is 0.027 . Thus, based on experimental data, it should be expected that the best samples of IRC will reduce the ice friction resistance component at least to 2.85 times. The total ice resistance reduces at least to $20 \%$. But as a rule, in real conditions, the part of navigation route cowered with ice is no more than $50 \%$ of the total length of the navigation route. On the base of this fact, we can conclude that the real effect of using the best samples of IRC will be about $10 \%$.

\section{Evaluation of energy efficiency of ice-going ships}

The IRC reduces ice friction coefficient, operational loads and main engine power as a result reduce the gas emissions into the atmosphere.

The effective power $\mathrm{P}$ is determined as the product of the resistance force to ship speed:

$$
P=\mathrm{R} \cdot \mathrm{v}
$$

where $v$ - ship speed; $\mathrm{R}$ - total ice resistance. 
For the case when the total ice resistance force will be reduced to $10 \%$ (in according with eq. (5))than the effective power of main engine can be written as:

$$
\begin{aligned}
& 0,9 P=0,9 \mathrm{R} \cdot v \\
& P=0,9 \mathrm{R} \cdot \frac{10}{9} v
\end{aligned}
$$

Thus, the advantages of IRC are following:

- at design and construction stages - reduce the total ship weight and main engine power;

- at operation stage - reduction of main engine loads and fuel consumption, increase the speed, reduce the $\mathrm{CO}$ emission and generally reduce the cargo transportation costs.

In according with GOST R 56163-2014 "Emissions of pollutants into the atmosphere", the maximum emission of the $\mathrm{i}^{\text {th }}$ substance, $\mathrm{g} / \mathrm{s}$, by a diesel engine is calculated as [8]:

$$
M_{i}=\frac{e_{M i} \cdot P_{e}}{3600}
$$

where: $e_{M i}$ - emission of the $\mathrm{i}^{\text {th }}$ harmful substance, $\mathrm{g} / \mathrm{kWh} ; P_{\ni}$ - operating power of a diesel engine $\mathrm{kW}$.

The influence of ice-resistant coatings characteristics to the energy efficiency of ice-going are shown in Table 4.

Table 4. Effect of using IRC

\begin{tabular}{|c|c|c|c|c|c|c|c|}
\hline$\mu_{\mathrm{k}}$ & 0.08 & 0.07 & 0.06 & 0.05 & 0.04 & 0.03 & 0.027 \\
\hline $\mathrm{R}, \mathrm{kN}$ & 1981 & 1909 & 1837 & 1765 & 1694 & 1622 & 1600 \\
\hline $\mathrm{P}_{\ni}, \mathrm{kW}$ & 3962 & 3818 & 3674 & 3531 & 3387 & 3243 & 3200 \\
\hline$M_{C O}, \mathrm{~g} / \mathrm{s}$ & 7,92 & 7,64 & 7,35 & 7,06 & 6,77 & 6,49 & 6,40 \\
\hline$M_{N O x}, \mathrm{~g} / \mathrm{s}$ & 11,89 & 11,45 & 11,02 & 10,59 & 10,16 & 9,73 & 9,60 \\
\hline$M_{C H}, \mathrm{~g} / \mathrm{s}$ & 3,96 & 3,82 & 3,67 & 3,53 & 3,39 & 3,24 & 3,20 \\
\hline$M_{C}, \mathrm{~g} / \mathrm{s}$ & 0,66 & 0,64 & 0,61 & 0,59 & 0,56 & 0,54 & 0,53 \\
\hline$M_{\text {SO2 }, \mathrm{g} / \mathrm{s}}$ & 1,32 & 1,27 & 1,22 & 1,18 & 1,13 & 1,08 & 1,07 \\
\hline$M_{\text {CH2O }, \mathrm{g} / \mathrm{s}}$ & 0,17 & 0,16 & 0,15 & 0,15 & 0,14 & 0,14 & 0,13 \\
\hline$M_{\text {Benzo(a)pyrene, }} \mathrm{g} / \mathrm{s} * 10^{-5}$ & 1,43 & 1,38 & 1,33 & 1,27 & 1,22 & 1,17 & 1,16 \\
\hline
\end{tabular}

At present results, we can conclude that the emission is directly proportional to the effective power of main engine fuel consumption.

For the express calculation of the influence of ice-resistant coatings characteristics to the energy efficiency of ice-going ships by means the eq. (6) - (8) the nominal engine power of main engine $\left(N_{e}\right), \mathrm{kW}$, can be used as $P_{e}[7]$.

\section{Conclusion}

The IRC developed for icebreakers and ice-going ships pass throw the mandatory certification by the international classification. Such coatings have an impaction on the design and operational stages.

At present paper, the results of IRC experimental tests are shown. The real range of friction coefficient values is formed 0,027-0,077.

The assessment of ice-resistant coatings characteristics to ice resistant and the energy efficiency of ice-going ships were performed. The total resistant force can be decrease to 10 - $20 \%$ if apply the best types of IRC. The emission is directly depend of effective power of main engine and fuel consumption thus the IRC will reduce the harmful effect. 


\section{References}

1. I.V. Sovel'ev, Kursobshchejfiziki, kn.1: mekhanika, 336 p., (2008)

2. Rules for the Classification and Construction of Sea-Going Ships, part XIII «Materials», Russian Maritime Register of Shipping, 285 p.(2020).

3. V.A. Veselov, M.V. Kitaev, P.O. Pastukhov, O.E. Surov., Tests of paint and varnish iceresistant protective coatings of ice class vessels, IOP Conference Series, №986, P. 111(2020).

4. ISO 12944-6-2009. Paints and varnishes. Steel structures rust protection by protective coating systems. Part 6.Laboratorytest methods, 20p, (2009).

5. ISO 12944-2. Paints and varnishes. Steel structures rust protection by protective coating systems. Part 6.Environment classification, 16p, (2009).

6. ISO 5725. Accuracy (correctness and precision) of measurement methods and results (2002).

7. B.P. Ionov, U.M. Gramuzov., Ledovayahodkost' sudov, 504 p., (2013).

8. GOST R 56163-2014 Emissions of pollutants into the atmosphere", Method for calculating pollutant emissions from stationary diesel engines, 6 p. (2014) 